\title{
Bilateral upper extremity severe ecchymosis in a patient on alirocumab, rivaroxaban, and clopidogrel therapy
}

Parth R Shah, Charles J Glueck, Vybhav Jetty

Jewish-Mercy Cholesterol and Metabolism Center, USA

Received: January 13, 2016

Accepted: February 28, 2016

Online Published: March 4, 2016

DOI: $10.5430 /$ crim.v3n2p11

URL: http://dx.doi.org/10.5430/crim.v3n2p11

\begin{abstract}
The PCSK9 inhibitors, alirocumab and evolocumab, are a new class of powerful LDL cholesterol lowering agents which allow previously unattainable lowering of LDL cholesterol (LDLC). Once past the necessarily restrictive confines of placebo-controlled clinical trials, in current medical practice, some patients with concomitant thromboembolism and arterial disease may also be taking potent anticoagulants and/or anti-platelet agents in addition to PCSK9 inhibitors. There are currently no reports on drug interactions and no warnings when alirocumab or evolocumab are used in conjunction with anticoagulants and/or anti-platelet therapy. Here, we present a case of patient with exceptional LDLC lowering (LDLC $<4 \mathrm{mg} / \mathrm{dl}$ ) on alirocumab $150 \mathrm{mg} / \mathrm{ml}$ every 2 weeks and concomitant anti-platelet (clopidogrel $75 \mathrm{mg} /$ day) and anti-coagulation therapy (rivaroxaban $10 \mathrm{mg} /$ day) because of recurrent non-cardiogenic amaurosis fugax, and transient ischemic attacks, and ischemic stroke associated with heterozygosity for the G20210A prothrombin gene mutation. On this regimen, the patient developed gradually spreading intensive skin ecchymosis and bleeding on both arms. This resolved after stopping alirocumab, clopidogrel, and rivaroxaban, and did not reappear when clopidogrel and rivaroxaban were restarted without alirocumab.
\end{abstract}

Key Words: PCSK9 inhibitors, Alirocumab, Cholesterol, Clopidogrel, Rivoraxaban, Anti-platelet, Anti-coagulation

\section{INTRODUCTION}

LDL cholesterol (LDLC) lowering beyond the lowest levels achievable with maximal diet-drug regimens has been revolutionized by PCSK9 inhibitors, which are indicated as an adjunct to diet-maximally tolerated cholesterol lowering drug therapy in heterozygous $(\mathrm{HeFH})$ or homozygous $(\mathrm{HoFH})$ familial hypercholesterolemia, and/or clinical atherosclerotic cardiovascular disease (CVD) where LDLC lowering is insufficient despite maximal tolerated therapy. Alirocumab ODYSSEY Phase III studies demonstrated that the mean percentage change in calculated LDL cholesterol level from baseline to week 24 was $61 \%$ (alirocumab) vs.
$0.8 \%$ (placebo), $p<.001 .^{[1]}$ In 2,461 patients treated with alirocumab, 796 (32\%) had two consecutive LDLC levels < $25 \mathrm{mg} / \mathrm{dl}$ while 288 (12\%) had two consecutive LDLC levels $<15 \mathrm{mg} / \mathrm{dl} .{ }^{[2]}$ Furthermore, in the OSLER-1 and OSLER-2 phase III trials, evolocumab reduced LDL cholesterol levels by $61 \%$ at 12 -week on-treatment median. ${ }^{[3]}$ In a pool of 2,651 evolocumab-receiving patients, 1,609 (61\%) had at least one LDLC $<25 \mathrm{mg} / \mathrm{dl}$. ${ }^{[4]}$

Compared to the placebo, there were minimal adverse reactions to the PCSK9 inhibitors with differences between placebo vs. PCSK9 inhibitor group consistently <

*Correspondence: Charles J Glueck; Email: cjglueck@ mercy.com; Address: Jewish-Mercy Cholesterol and Metabolism Center, USA. 
$2 \% .^{[2,4]}$ Injection site reactions occur in approximately $7.2 \%$ (alirocumab) vs. 5.1\% (placebo) of enrolled subjects in the studies, and allergic reactions have been reported to be $8.6 \%$ (alirocumab) vs. $7.8 \%$ (placebo). ${ }^{[2]}$ Injection site reactions occur in approximately $3.2 \%$ (evolocumab) $v s$ $3.0 \%$ (placebo) subjects, while allergic reactions were $5.1 \%$ (evolocumab) vs. $4.6 \%$ (placebo). ${ }^{[4]}$ There are no drug to drug interaction data or warnings when using alirocumab or evolocumab in conjunction with anticoagulants and/or anti-platelet therapy.

\section{Case report}

The patient, a 70-year-old non-smoking Caucasian male, was referred to our center because of non-cardiogenic recurrent amaurosis fugax, and transient ischemic attacks (TIAs) and ischemic strokes in the presence of normal carotid and coronary artery imaging, and in the absence of atrial fibrillation. He was found to be heterozygous for the G20210A prothrombin gene mutation, which is known to be associated with retinal artery thrombotic occlusion, amaurosis fugax, ${ }^{[5,6]}$ and ischemic stroke, ${ }^{[7,8]}$ as well as, more commonly, venous thrombosis. ${ }^{[9-13]}$ Due to increased frequency of amaurosis fugax episodes and ischemic stroke-TIAs, ${ }^{[14]}$ he was initially anticoagulated with enoxaparin ( $1 \mathrm{mg} / \mathrm{kg} / \mathrm{twice}$ per day), with a sharp reduction in the frequency of amaurosis fugax attacks, and non-recurrence of TIAs and ischemic strokes. He was subsequently anticoagulated with rivaroxaban (10 $\mathrm{mg}$ /day) for 3 years. However, after reoccurrence of TIAs despite rivaroxaban, clopidogrel $75 \mathrm{mg} /$ day $^{[14]}$ was added, and continued uneventfully without skin bruising or bleeding for 1 year.

Our initial evaluation revealed heterozygous familial hypercholesterolemia as per Simon Broome's criteria. ${ }^{[15]}$ Despite a low cholesterol and low saturated fat diet plus rosuvastatin $40 \mathrm{mg}$ and ezetimibe $10 \mathrm{mg}$, the lowest LDLC achieved was $144 \mathrm{mg} / \mathrm{dl}$. Given the patient's history of TIAs and ischemic stroke, our target was LDLC $<70 \mathrm{mg} / \mathrm{dl}^{\left[{ }^{[16,17]}\right.}$ Unable to attain LDLC $<70 \mathrm{mg} / \mathrm{dl}$ despite maximally tolerated cholesterol lowering therapy, he met FDA indications for PCSK9 therapy, and alirocumab $150 \mathrm{mg} / \mathrm{ml}$ was started subcutaneously every two weeks to achieve a LDLC target $<70$ $\mathrm{mg} / \mathrm{dl}$.

After being on alirocumab $150 \mathrm{mg}$ every 2 weeks for 6 weeks (3 doses), the patient presented with a diffuse ecchymotichemorrhagic bruising on both arms which started as an area of central clearing followed by blood spreading out in a circular fashion. Blood oozed out from the ecchymotic sites intermittently, but there was no pain or tenderness (see Figure 1). Normal findings included platelet count $175 \times$ $10^{3}$, hemoglobin $14.7 \mathrm{~g} / \mathrm{dl}$, and hematocrit $44.7 \%$; there was no evidence of systemic bleeding. Factor VIII was not measured at the time of ecchymosis to rule out acquired hemophilia, but had been normal (110\%) before any anticoagulant or alirocumab therapy. Previous to development of the ecchymotic-bruising, four weeks after starting alirocumab, total cholesterol had fallen from 211 to $87 \mathrm{mg} / \mathrm{dl}$, and LDLC from 144 to $<4 \mathrm{mg} / \mathrm{dl}$. All other laboratory tests including complete blood count with differential and comprehensive metabolic panel were normal after four weeks on alirocumab.

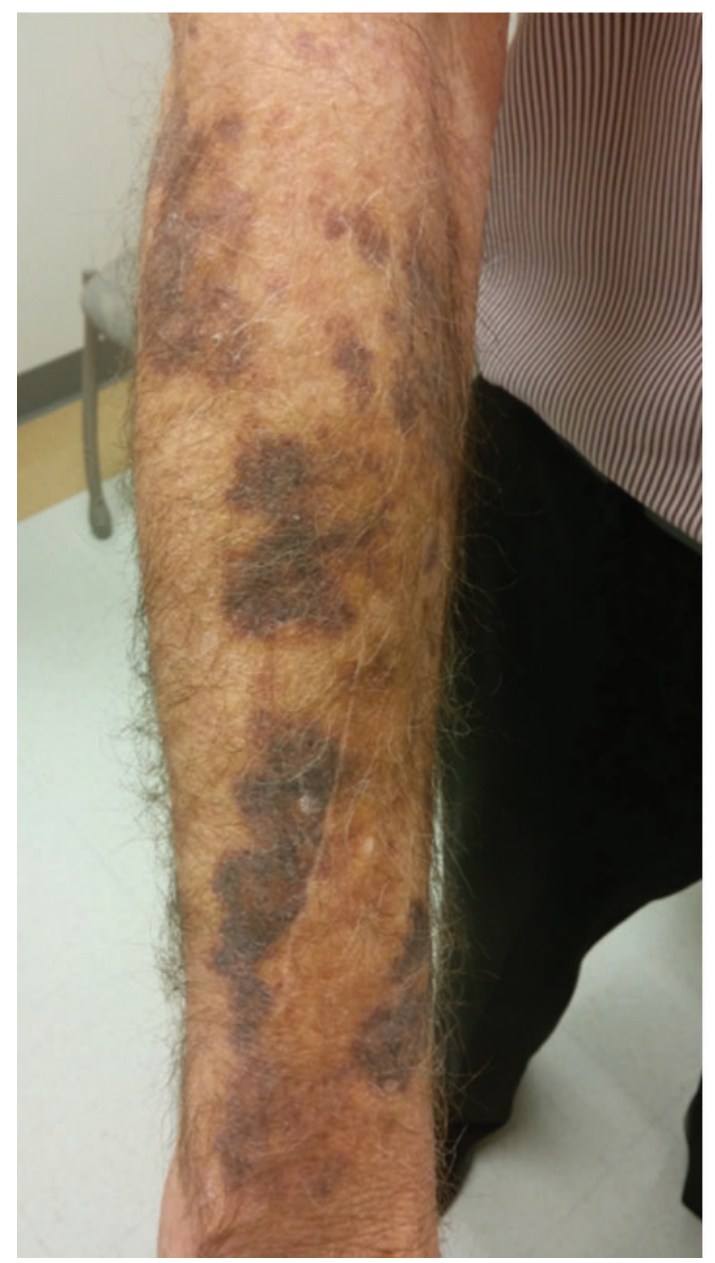

Figure 1. Ecchymosis, bruising, and bleeding into the skin after 6 weeks of alirocumab with concomitant rivaroxaban and clopidogrel therapy

At week seven, after three doses of alirocumab and appearance of the ecchymosis and bruising and bleeding into the skin, we discontinued clopidogrel, rivaroxaban, and Alirocumab. Within 1 week, the ecchymosis-bruising had begun to fade and recede. Because the frequency of symptoms of amaurosis fugax accelerated markedly during the time period off anticoagulants, clopidogrel and rivaroxaban were uneventfully restarted, without recurrence of the hemorrhagic ecchymosis in the skin. After 6 weeks back on clopidogrel 
and rivaroxaban, there was no ecchymosis and no bruising and the forearm skin regained the same appearance as prior to alirocumab therapy (see Figure 2).

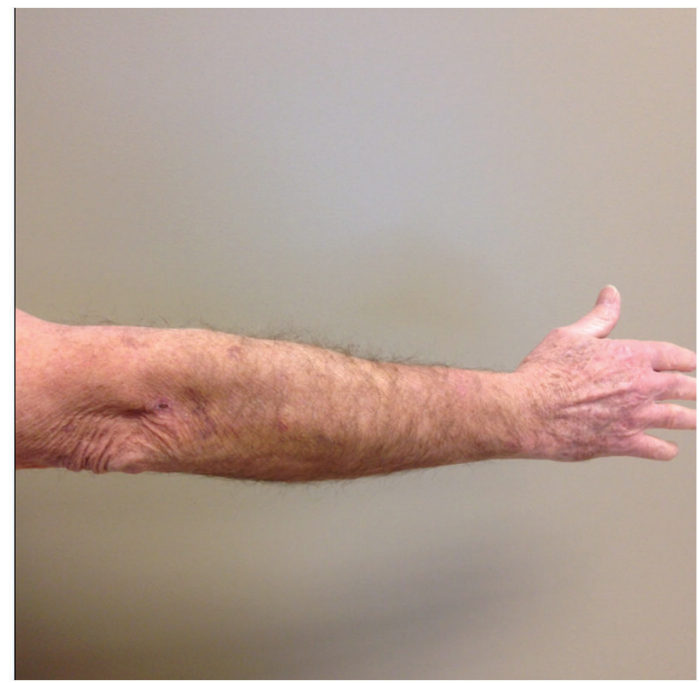

Figure 2. Six weeks after stopping alirocumab and restarting rivaroxaban and clopidogrel therapy

\section{Discussion}

Could the alirocumab-driven reduction of LDLC to $<4 \mathrm{mg} / \mathrm{dl}$ in the presence of concurrent rivaroxaban and clopidogrel therapy have led to the extensive ecchymosis in the skin which resolved quickly (6 weeks) after alirocumab was discontinued? In abetalipoproteinemia, a condition in which LDLC is close to zero, platelets have a decreased response to aggregating stimuli ${ }^{[18,19]}$ and the low levels of LDLC are thought to affect the clearance rate of plasma plateletactivating factor acetylhydrolase, thus reducing platelet aggregation. ${ }^{[20]}$

As shown by the controlled clinical drug trial data for alirocumab and evolocumab, patients are now frequently able to attain LDLC $<25 \mathrm{mg} / \mathrm{dl} .{ }^{[2,4]}$ In safety data from the JUPITER trial involving rosuvastatin $20 \mathrm{mg}$, when patients attained LDLC $<30 \mathrm{mg} / \mathrm{dl}$, there was an increased physician reporting of hematuria, without statistically significant increased risk for hemorrhagic stroke. ${ }^{[14,21]}$

When LDLC is lowered in patients with normal high den- sity lipoprotein cholesterol (HDLC), there is a significant decrease in platelet activation. ${ }^{[22]}$ Previous studies with atorvastatin $20 \mathrm{mg} /$ day therapy revealed that it normalized platelet hyperfunction and significantly reduced GPIIb/IIIa response to ADP. ${ }^{[23]}$ When atorvastatin $20 \mathrm{mg} /$ day was given to patients with high LDLC and low HDLC vs. high LDLC and normal HDLC, platelet activation was not significantly decreased in the high LDLC and low HDLC versus high LDLC and normal HDLC group. ${ }^{[22]}$

Increased LDL cholesterol is associated with increased platelet aggregation. ${ }^{[22-25]}$ Hypercholesterolemic patients have been shown to have high percentage of GPIIb/IIIaphosphatidylserine, and CD62p positive platelets, increased plasma viscosity, and high erythrocyte aggregation index compared to controls. ${ }^{[22-24]}$ Furthermore, in hypercholesterolemic individuals, platelets generate oxidized-LDL which leads to more platelet aggregation. ${ }^{[25]}$

We cannot completely rule out the unlikely possibility of drug induced transient acquired hemophilia leading to the ecchymosis and bruising in the skin. Acquired hemophilia, affecting factor VIII, is very rare and occurs in about one in a million people, with women affected 55\% of the time. Drugs known to be associated with acquired hemophilia include penicillin, sulfonamides, chloramphenicol, diphenylhydantoin, fludarabine, and interferon- $\alpha$, none of which had been given to our patient. ${ }^{[26-28]}$

For patients with heterozygous familial hypercholesterolemia, and/or cardiovascular disease with suboptimal LDLC lowering despite maximal tolerated conventional dietdrug therapy, ${ }^{[1,3]}$ PCSK9 therapy provides a very effective new therapeutic avenue. In those patients receiving PCSK9 therapy, who, as in the current case, require concurrent antiplatelet and factor Xa inhibition, further studies need to be done to determine whether extraordinary LDLC lowering mediated by PCSK9 therapy may affect the platelet function, thus facilitating development of ecchymotic bruisingbleeding into the skin when accompanied by clopidogrel and/or rivaroxaban.

\section{CONFlicts of InTEREST Disclosure}

The authors have declared no conflicts of interest.

\section{REFERENCES}

[1] Robinson JG, Farnier M, Krempf M, et al. Efficacy and safety of alirocumab in reducing lipids and cardiovascular events. N Engl J Med. 2015; 372(16): 1489-99. PMid:25773378 http://dx.doi .o $\mathrm{rg} / 10.1056 /$ NEJMoa1501031

[2] Praluent [package insert]. Sanofi-Aventis U.S. LLC, Bridgewater,
NJ; October 2015. February 15, 2016. Available from: http: //www.regeneron.com/Praluent/Praluent-fpi.pdf

[3] Sabatine MS, Giugliano RP, Wiviott SD, et al. Efficacy and safety of evolocumab in reducing lipids and cardiovascular events. N Engl J Med. 2015; 372(16): 1500-9. PMid:25773607 http://dx.doi.o rg/10.1056/NEJMoa1500858 
[4] Repatha [package insert]. Amgen, Inc., Thousand Oaks, CA; 2015.

[5] Schockman S, Glueck CJ, Hutchins RK, et al. Diagnostic ramifications of ocular vascular occlusion as a first thrombotic event associated with factor V Leiden and prothrombin gene heterozygosity. Clin Ophthalmol. 2015; 9: 591-600. PMid:25897198 http: //dx.doi.org/10.2147/OPTH.S80714

[6] Glueck CJ, Golnik K, Wang P. Amaurosis fugax caused by heritable thrombophilia-hypofibrinolysis in cases without carotid atherosclerosis: thromboprophylaxis prevents subsequent transient monocular partial blindness. Clin Appl Thromb Hemost. 2007; 13(2): 124-9. PMid:17456620 http://dx.doi.org/10.1177/1076029 606298735

[7] Van der Meer FJM, Koster T, Vandenbroucke JP, et al. The Leiden Thrombophilia Study (LETS). Thromb Haemost. 1997; 78(1): 631-5. PMid:9198229

[8] Lalouschek W, Schillinger M, Hsieh K, et al. Matched case-control study on factor V Leiden and the prothrombin G20210A mutation in patients with ischemic stroke/transient ischemic attack up to the age of 60 years. Stroke. 2005; 36(7): 1405-9. PMid:15947254 http: //dx.doi.org/10.1161/01.STR.0000170635.45745.b8

[9] Emmerich J, Rosendaal FR, Cattaneo M, et al. Combined effect of factor V Leiden and prothrombin 20210A on the risk of venous thromboembolism-pooled analysis of 8 case-control studies including 2310 cases and 3204 controls. Study Group for Pooled-Analysis in Venous Thromboembolism. Thromb Haemost. 2001; 86(3): 80916. PMid: 11583312

[10] Rosendaal FR, Doggen CJM, Zivelin A, et al. Geographic distribution of the $20210 \mathrm{G}$ to A prothrombin variant. Thromb Haemost. 1998; 79(4): 706-8. PMid:9569177

[11] Lijfering WM, Middeldorp S, Veeger NJGM, et al. Risk of recurrent venous thrombosis in homozygous carriers and double heterozygous carriers of factor V Leiden and prothrombin G20210A. Circulation. 2010; 121(15): 1706-12. PMid:20368522 http://dx.doi.org/1 0.1161 /CIRCULATIONAHA . 109.906347

[12] Lijfering WM, Rosendaal FR, Cannegieter SC. Risk factors for venous thrombosis - current understanding from an epidemiological point of view. Br J Haematol. 2010; 149(6): 824-33. PMid:20456358 http://dx.doi.org/10.1111/j.1365-2141.2010.08206.x

[13] Endler G, Mannhalter C. Polymorphisms in coagulation factor genes and their impact on arterial and venous thrombosis. Clin Chim Acta 2003; 330(1-2): 31-55. http://dx.doi.org/10.1016/S0009-8 981 (03) 00022-6

[14] Kernan WN, Kasner SE, Adams RJ, et al. Guidelines for the prevention of stroke in patients with stroke and transient ischemic attack: a guideline for healthcare professionals from the American Heart Association/American Stroke Association. Stroke. 2014; 45(7): 2160 236. PMid:24788967 http://dx.doi.org/10.1161/STR. 00000 00000000024

[15] Risk of fatal coronary heart disease in familial hypercholesterolaemia. Scientific Steering Committee on behalf of the Simon Broome
Register Group. BMJ. 1991; 303(6807): 893-6. PMid:1933004 http://dx.doi.org/10.1136/bmj.303.6807.893

[16] Cannon CP, Braunwald E, McCabe $\mathrm{CH}$, et al. Intensive versus moderate lipid lowering with statins after acute coronary syndromes. N Engl J Med. 2004; 350(15): 1495-504. PMid:15007110 http: //dx.doi.org/10.1056/NEJMoa040583

[17] Cannon CP, Blazing MA, Giugliano RP, et al. Ezetimibe Added to Statin Therapy after Acute Coronary Syndromes. N Engl J Med 2015; 372(25): 2387-97. PMid:26039521 http://dx.doi.org/1 $0.1056 /$ NEJMoa1410489

[18] Croft KD, Beilin LJ. Platelet and neutrophil function and eicosanoid release in a subject with abetalipoproteinaemia. Thromb Res. 1993; 69(4): 333-42. http://dx.doi.org/10.1016/0049-3848(93 ) $90032-\mathrm{J}$

[19] Surya II, Mommersteeg M, Gorter G, et al. Abnormal platelet functions in a patient with abetalipoproteinemia. Thromb Haemost. 1991; 65(3): 306-11. PMid:1904656

[20] Guerra R, Zhao B, Mooser V, et al. Determinants of plasma platelet-activating factor acetylhydrolase: heritability and relationship to plasma lipoproteins. J Lipid Res. 1997; 38(11): 2281-8. PMid:9392426

[21] Moscardo A, Vallés J, Latorre A, et al. The association of thromboxane A2 receptor with lipid rafts is a determinant for platelet functional responses. FEBS Lett. 2014; 588(17): 3154-9. PMid:24996187 http://dx.doi.org/10.1016/j.febslet.2014.06.057

[22] Chan LW, Luo XP, Ni HC, et al. High levels of LDL-C combined with low levels of HDL-C further increase platelet activation in hypercholesterolemic patients. Braz J Med Biol Res. 2015; 48(2): 167-73. PMid:25466164 http://dx.doi.org/10.1590/1414-431X201 44182

[23] Labios M, Martínez M, Gabriel F, et al. Effect of atorvastatin upon platelet activation in hypercholesterolemia, evaluated by flow cytometry. Thromb Res. 2005; 115(4): 263-70. PMid:15668185 http://dx.doi.org/10.1016/j.thromres.2004.08.016

[24] Contreras T, Vayá A, Palanca S, et al. Influence of plasmatic lipids on the hemorheological profile in healthy adults. Clin Hemorheol Microcirc. 2004; 30(3-4): 423-5. PMid:15258378

[25] Carnevale R, Bartimoccia S, Nocella C, et al. LDL oxidation by platelets propagates platelet activation via an oxidative stress-mediated mechanism. Atherosclerosis. 2014; 237(1): 10816. PMid:25238217 http://dx.doi.org/10.1016/j.atheros clerosis.2014.08.041

[26] Franchini M, Capra F, Nicolini N, et al. Drug-induced anti-factor VIII antibodies: a systematic review. Med Sci Monit. 2007; 13(4): RA55-61. PMid:17392659

[27] Franchini M, Gandini G, Di Paolantonio T, et al. Acquired hemophilia A: a concise review. Am J Hematol. 2005; 80(1): 55-63. PMid:16138334 http://dx.doi.org/10.1002/ajh. 20390

[28] Sborov DW, Rodgers GM. Acquired hemophilia: a current review of autoantibody disease. Clin Adv Hematol Oncol. 2012; 10(1): 19-27. PMid:22398803 